\title{
(DES)ACERTOS NO JULGAMENTO DA LEI DE ANISTIA DE 1979: O SUPREMO TRIBUNAL FEDERAL E A JURISPRUDÊNCIA DA CORTE INTERAMERICANA DE DIREITOS HUMANOS SOBRE AUTOANISTIA
}

\author{
(UN)CORRECT IN THE JUDGMENT OF THE AMNESTY LAW OF 1979: THE SUPREME \\ COURT AND THE JURISPRUDENCE OF THE INTER-AMERICAN COURT OF HUMAN \\ RIGHTS ON AUTO-AMNESTY
}

David Barbosa de Oliveira

\author{
Doutor em Direito pela Universidade Federal de Pernambuco - UFPE. Professor \\ adjunto da Universidade Federal do Ceará - UFC. Professor colaborador do Mestrado e \\ doutorado em Sociologia da Universidade Estadual do Ceará - UECE. \\ E-mail: dvdbarol@gmail.com
}

Recebido em: 21/03/2017

Aprovado em: 30/06/2017

\begin{abstract}
RESUMO: Este artigo busca refletir sobre a utilização pelo Supremo Tribunal Federal - no julgamento da Arguição de Descumprimento de Preceito Fundamental número 153, que decidiu se a Lei de Anistia de 1979 teria sido recepcionada pela Constituição de 1988 - da jurisprudência da Corte Interamericana de Direitos Humanos sobre o assunto. A fim de dar conta desse objeto, utilizamos metodologia bibliográfica e pesquisa documental. Nosso objetivo é analisar como os ministros do Supremo Tribunal Federal se utilizaram da jurisprudência da Corte Interamericana de Direitos Humanos para fundamentar seus votos, analisando se as decisões estão em consonância. Como resultado, encontramos disparidades interpretativas significativas entre os dois tribunais, posto que os votos vencedores do Supremo Tribunal Federal deram entendimento que contrasta com as decisões da Corte Interamericana de Direitos Humanos.
\end{abstract}

Palavras-chave: Anistia. Supremo Tribunal Federal. Corte Interamericana de Direitos Humanos. Arguição de Descumprimento de Direito Fundamental número 153. Direitos Humanos.

ABSTRACT: This article seeks to reflect on the use by the Federal Supreme Court in the judgment of the Argument of Noncompliance of Fundamental Precept number 153, which decided whether the amnesty law of 1979 would have been approved by the 1988 Constitution, the jurisprudence of the Inter-American Court of Human Rights on the subject. In order to account for this object we use bibliographic methodology and documentary research. The purpose of this article is to analyze how the ministers of the Federal Supreme Court have used the jurisprudence of the Inter-American Court of Human Rights to substantiate their votes, analyzing whether the decisions are in line. As a result, we find significant interpretative disparities between the two courts, since the victorious votes of the Federal Supreme Court gave an understanding that contrasts with the decisions of the Inter-American Court of Human Rights.

Keywords: Amnesty. Federal Court of Justice. Inter-American Court of Human Rights. Argument of Non-compliance with Fundamental Law number 153. Human Rights.

SUMÁRIO: Introdução. 1 A Lei de Anistia de 1979: um introito necessário. 2 Julgamento da Lei de Anistia pelo STF: um problema transconstitucional. 3 O (des)acerto na utilização da 
jurisprudência da Corte Interamericana de Direitos Humanos para justificar a interpretação de anistia bilateral pelo Supremo Tribunal Federal. Conclusão. Referências Bibliográficas.

\section{INTRODUÇÃO}

A anistia é assunto que carrega contradições e disputas por seu sentido. As contradições decorrem, em parte, da má compreensão do instituto. Em 10 de dezembro de 2014, o jornal O Globo (2015) exibiu a manchete Comissão da Verdade pede revogação parcial da Lei da Anistia e responsabiliza ex-presidentes. Meses antes, militares reunidos no Rio de Janeiro lançaram Carta Aberta à Presidente da República, denunciando os tratamentos discriminatórios pelo Ministério da Defesa a eles, exigindo o cumprimento da Lei de Anistia. A carta dos militares anistiados divulgada em 23 de junho de 2014, entre os festejos da Copa do mundo de futebol, buscava chamar a atenção da sociedade para o problema dos militares anistiados políticos ${ }^{1}$. Mas como podemos explicar o aparente paradoxo de vermos movimentos sociais que militam em um mesmo campo social e possuem interesses convergentes pedirem, a um só tempo, a revogação/cumprimento da Lei de Anistia? A resposta consiste no fato de se tratarem de duas anistias distintas que estão presentes no mesmo texto legal.

A Lei de Anistia de 1979, que inaugura o último ciclo anistiador, estende-se até os dias atuais e possui tanto normas que versam sobre a extinção de punibilidade dos tipos políticos e comuns cometidos no período, quanto normas de reparação dos anistiados. Assim, quando se requer que a Lei de Anistia seja revogada ou tida como não válida - como se deu com a Arguição de Descumprimento de Preceito Fundamental no 153 e com o caso Gomes Lund versus Brasil na Corte Interamericana de Direitos Humanos - relaciona-se à parte penal da Lei de Anistia de 1979. Entretanto, quando se afirma que a Lei de 1979 e os demais instrumentos anistiadores devem ser cumpridos, refere-se à parte reparadora da anistia, que pode ser encontrada, além de em outras comissões, nos requerimentos junto a Comissão de Anistia do Ministério da Justiça. Esse falso paradoxo mostra a atualidade do problema, assim como o desconhecimento de grande parte da população sobre a questão.

Nossa pesquisa vincula-se não ao aspecto reparador do instituto da anistia, mas à sua porção penal. Assim, buscamos refletir sobre o julgamento da Lei de Anistia de 1979, em verdade e mais especificamente sobre a interpretação dada a essa Lei pelo Supremo Tribunal Federal (STF) no processo de Arguição de Descumprimento de Preceito Fundamental número 153. Esse julgamento decidiu se a Lei de Anistia de 1979 teria sido recepcionada pela Constituição de 1988.

Há nesse trabalho um claro exemplo de questão transconstitucional, onde se entrelaçam problemas de ordens constitucional e internacional, ou, ainda mais especificamente, um transconstitucionalismo pluridimensional de direitos humanos (NEVES, 2009). Interessa-nos, portanto, entender como o STF, no julgamento da ADPF 153, utilizou-se da jurisprudência da Corte Interamericana de Direitos Humanos (CIDH) sobre leis de anistia e verificar o que se entende, por exemplo, como autoanistia nesses tribunais.

A fim de dar conta desse objeto, utilizamos metodologia bibliográfica e pesquisa documental, buscando analisar como os ministros do Supremo Tribunal Federal se utilizaram da jurisprudência da Corte Interamericana de Direitos Humanos para fundamentar seus votos, verificando se esse transconstitucionalismo é consistente, havendo consonância interpretativa, e se há coerência do STF no uso da jurisprudência da CIDH.

\footnotetext{
${ }^{1}$ Documento disponibilizado por José Bezerra da Silva, advogado e militar anistiado que participou do protesto. Revista de Direito Brasileira | São Paulo, SP | v. 19 | n. 8 | p. 382 - 394 |Jan./Abr. 2018
} 


\section{A LEI DE ANISTIA DE 1979: UM INTROITO NECESSÁRIO}

A lei 6.683 de 1979 não foi a primeira anistia publicada no Brasil. A anistia, no início do Estado Moderno, segundo Foucault (2006), era percebida mais como arbítrio do que como instrumento fomentador da paz social, posto que o monarca, além de dizer a lei penal, podia intervir no curso regular da justiça pelos perdões ou pressões diretas sobre os magistrados. A discricionariedade do rei, de punir ou agraciar, segundo Moraes, "conduziu frequentemente ao uso imoderado da indulgência soberana, o que não passou desapercebido aos políticos e publicistas da época, preocupados em assegurar o prestígio das normas penais" (1979, p. 5). Apenas na metade do século XVIII, estabeleceu-se uma nova economia de poder que substituiu o arbítrio real pela pena como consequência natural do crime. A infração não agride mais diretamente a pessoa do rei, mas todo o corpo social. Essa nova gestão do poder de punir se reflete também no uso da graça e das suas espécies, pois, como Beccaria (2009) aduz, o direito de conceder graça é uma improbação tácita das leis coletivas, um decreto geral de impunidade.

Para Martins (1978), em quase todos os momentos importantes da história nacional e em todas as suas fases - Colônia, Reino, Império e República - a anistia esteve presente, constatando-se, segundo o autor, "a existência de quase cem decretos de anistia" (MARTINS, 1978, p. 110). Apenas na Conjuração Baiana e na Inconfidência Mineira - nas quais os participantes, em regra, foram severamente punidos, inclusive com suplício - não foram concedidas anistias a nenhum dos envolvidos. Desse modo, em regra, seguiu-se por toda a história nacional: após uma revolução havia uma anistia. E isso se deu até o último processo de apaziguação social da história nacional, que se inicia com a lei $\mathrm{n}^{\circ} 6.683 / 79$.

A repressão desencadeada pelo estado de exceção, iniciada em 1964, contra os grupos de oposição política atingiu milhares de pessoas envolvidas, ou não, com a luta armada, daí bem antes de 1979, antes mesmo do Ato Institucional $\mathrm{n}^{\circ}$ 5, algumas vozes já exigiam anistia política. Em 1965, Carlos Heitor Cony, por exemplo, conforme atesta Martins, já assinalava que "desde $1^{\circ}$ de abril que o governo tem diante de si um dilema incontornável: ou processa e condena regularmente os milhares de acusados em todo o País; ou concede anistia" (1978, p. 123). Mesmo entre os setores militares havia vozes pró-anistia, como o general Pery Bevilácqua, em 1966, afirmando que "a nação não deve permanecer muito tempo dividida, entre vencedores e vencidos. (...) Sou por uma anistia ampla que abranja todos os cidadãos tidos como subversivos e como tal punidos, ou em vias de o ser, por motivos políticos" (MARTINS, 1978, p. 123).

Em 1968, articulou-se uma frente ampla que pudesse reunir tantos setores da oposição quanto apoiadores do golpe, defendendo uma anistia geral, dissipando a atmosfera de guerra civil que existia no país, contudo, ela foi fechada com o Ato Institucional $\mathrm{n}^{\circ} 5$. Ainda em 1968, o deputado Paulo Marcani (MDB-SC) apresentou projeto que concedia anistia a todos os estudantes, trabalhadores e intelectuais punidos, porém, em 20 de agosto do mesmo ano, o projeto foi derrotado no Congresso. Mas o passo definitivo para a anistia foi a formação do Movimento Feminino pela Anistia (MFPA), por iniciativa da advogada Terezinha Zerbini.

Para Skidmore, "embora os problemas econômicos fossem urgentes, uma das primeiras e mais importantes decisões de Figueiredo foi política" (1991, p. 423) com a apresentação do projeto de Lei de Anistia. É importante ressaltar que, em 1969, com a Emenda Constitucional $\mathrm{n}^{\circ}$ 1, deslocou-se do Congresso para o chefe do Executivo a competência da iniciativa para propor a Lei de Anistia, cabendo ao Legislativo, a partir de então, apenas discutir e deliberar. Essa medida foi determinante para os objetivos da anistia (penal) dos atos dos militares e tem um forte teor autoritário. Deste modo, restou à oposição apenas referendar os termos da anistia do governo, pois a maioria do plenário era arenista, não havendo, portanto, possibilidade de a oposição emedebista alterar o projeto iniciado no Executivo. Esse é um ponto muito importante nessa discussão, pois muitos, ao falarem da Lei de Anistia - inclusive alguns ministros do STF, na 
decisão da $\mathrm{ADPF} \mathrm{n}^{\circ} 153$ - afirmam que a anistia foi um consenso da sociedade brasileira, entretanto resta evidente o desequilíbrio entre os pactuantes.

Uma anistia, conforme explica Alves, "possibilitaria um desafogo de opinião pública ao mesmo tempo desarticulando um amplo movimento social que se mobilizara em torno da questão da anistia aos presos por motivo de opinião" (1985, p. 268). Daí o projeto de lei no 14, de 1979, alcançar ambos os lados: tanto os antes chamados subversivos, quanto os militares que prenderam, torturaram e mataram. Esse projeto tanto extinguia a punibilidade (anistia penal) quanto reparava os anistiados, a partir do que se torna possível perceber dois discursos disputando o sentido e, por conseguinte, os efeitos da anistia: primeiro há o discurso que busca restringir o alcance da anistia penal a torturadores e agentes que romperam a legalidade do regime de exceção, assim como ampliar os fatos anistiáveis e os direitos albergados pela anistia reparadora; segundo, existe o discurso que busca restringir a anistia penal, não a concedendo a quem praticou atos de terrorismo, assalto, sequestro e atentado pessoal etc., assim como busca restringir o alcance e os direitos dos anistiados. Esses dois discursos revivem a dinâmica que se sucedeu, durante o regime de exceção, do governo e defensores do golpe com os subversivos e opositores do regime de exceção. Essa dualidade também remonta, em certa medida, aos discursos anteriores ao golpe entre nacionalistas e americanófilos.

A despeito de não ter sido o foco das discussões em plenário, a lei 6.683, além de tratar do esquecimento de alguns fatos jurídicos, também reparava a situação de alguns anistiados, mas de maneira a não reestabelecer o anistiado em todos os seus direitos. Os benefícios da anistia se estenderam aos dirigentes e representantes sindicais punidos pelos atos de exceção, bem como aos estudantes e aos empregados das empresas privadas que - por motivo de participação em grave ou em quaisquer movimentos reivindicatórios ou de reclamação de direitos regidos pela legislação social - hajam sido despedidos do trabalho ou destituídos de cargos administrativos ou de representação sindical etc.

Os militares anistiados tiveram ainda maior dificuldade de ver sua anistia realizada. As intempéries que esses militares haviam passado, por conta dos atos de exceção, por exemplo, não foram corrigidas pela anistia de 1979, havendo um discurso que perpetuava as diferenças instauradas a partir do regime de exceção, podendo até se falar de um discurso que continua a ideologia golpista. Assim, ao estabelecer aos anistiados o retorno ou a reversão ao serviço ativo para o mesmo cargo ou emprego, posto ou graduação que o servidor, civil ou militar, ocupava na data de seu afastamento, o texto da lei 6.683 não repara o tempo que o anistiado quedou fora da caserna. Dessa maneira, a Lei de Anistia não equiparava os direitos dos cassados aos direitos dos militares que, à época, estavam na ativa, não corrigindo a desigualdade criada pelo regime de exceção entre esses dois grupos. Mesmo sem o restabelecimento de todos os seus direitos, com o retorno do grupo dos militares anistiados à caserna, reinsere-se novamente a disputa ideológica entre militares de esquerda e de direita, ausente desde o golpe de 1964.

A anistia de 1979 foi, sem sombra de dúvida, um enorme passo para a redemocratização e a pluralidade da sociedade brasileira. Foi também a primeira vez, dentro do regime civil-militar, que os movimentos populares e organizados da sociedade se uniram em torno de um objeto em comum e conseguiram alcançar suas reinvindicações ante o poder público. Mas, essa anistia não era tão ampla, geral e irrestrita, posto que, como ressalta Henfil (1981), em 28 de agosto de 1979, "apesar de a gente ter conseguido uma anistia quase total, apesar do Betinho agora poder voltar, não dá para ficar feliz. Que foguetes poderemos soltar sem magoar os trezentos que, além de terem sido torturados feito cobaias, continuarão presos ou exilados?” (1981, p. 162). Muitos sujeitos e direitos, por conseguinte, ficaram fora dessa anistia, daí os movimentos de ampliação dessa graça dentro das constituições.

Essa norma, como podemos perceber, em nenhum momento gozou de consenso social, sendo seu objeto disputado até os dias atuais, dentro e fora do Estado. O dissenso sobre seu 
conteúdo findou em uma disputa por sua interpretação e sua validade na ADPF153 e é sobre esse julgamento que nos deteremos a seguir.

\section{JULGAMENTO DA LEI DE ANISTIA PELO STF: UM PROBLEMA TRANSCONSTITUCIONAL}

A lei de 1979 foi recentemente apreciada por dois tribunais: o Supremo Tribunal Federal e a Corte Interamericana de Direitos Humanos. Antes de uma análise mais detalhada sobre o julgamento da Lei de Anistia no STF, importa afirmar que esse já vinha utilizando o argumento do direito internacional em inúmeros julgados, como aponta Rothenburg, "para conferir densidade e capacidade de persuasão ao discurso jurídico" (2013, p. 686). Isso se deve ao fato de alguns problemas jurídicos perpassarem ordens jurídicas diversas, podendo uma ordem buscar modelos e razões para fundamentar suas escolhas em outra.

Tal fato permite que haja observações mútuas que fomentarão aprendizado e intercâmbio recíprocos entre cortes. Neves nomeou esse fenômeno de transconstitucionalismo, buscando explicar com ele o diálogo entre ordens normativas sobre questões constitucionais, ou seja, propicia delinear as formas de relação entre ordens jurídicas diversas. Segundo Neves, problemas constitucionais podem surgir em diversas ordens jurídicas, ou seja, "um mesmo problema de direitos fundamentais pode apresentar-se perante uma ordem estatal, local, internacional, supranacional e transnacional" (2009, p. 121). A Lei de Anistia de 1979 é um desses problemas que perpassam mais de uma ordem, espalhando-se por mais de uma corte.

A análise realizada pelos dois tribunais, o Supremo Tribunal Federal e a Corte Interamericana de Direitos Humanos, refere-se tão somente à parte de extinção da punibilidade decorrente da lei de 1979. Assim, não são questionados nas decisões desses dois órgãos nem a reparação do artigo $8^{\circ}$ e $9^{\circ}$ do Ato de Disposições Constitucionais Transitórias, nem as anistias constitucionais de 1985 pela emenda $\mathrm{n}^{\circ} 26$, nem a parte relativa à reparação dos perseguidos políticos da lei 6.683/79. Deste modo, tratamos aqui da discussão sobre a parte penal e não sobre a parte da reparação da graça de 1979. Entretanto, antes, para compreender melhor a problemática dos julgamentos pelas Cortes, urge compreender a distinção entre anistia absoluta e anistia condicionada.

A anistia pode ser classificada, no Direito Internacional, como anistia absoluta ou anistia condicionada. Quando a anistia é imposta sem qualquer tipo de responsabilização, como, por exemplo, dos agentes do Estado que agrediram Direitos humanos, sendo ditada pela tradicional e histórica ideia de total esquecimento dos fatos passados, ela é considerada uma autoanistia (anistia absoluta). Para Kai Ambos (2009), a finalidade primeira da anistia absoluta (anistia amnésica) é esconder completamente os crimes do passado, proibindo qualquer investigação sobre eles. Essa anistia é a concedida pelo próprio regime ditatorial aos crimes da repressão política promovida ou admitida por ela. Já a anistia condicionada não exime automaticamente de punição os fatos cometidos, sendo previsto sempre alguma forma de responsabilidade. Essa anistia é ditada pela ideia de compromisso e de memória, tanto que nela, pode haver, inclusive, a inserção da cláusula de revogação da anistia, que é usada quando uma das partes não cumpre o compromisso assumido. Para Kai Ambos, "solo este tipo de amnistia, que podria ser llamada amnistia responsable (accountable amnesty), puede ségun las condiciones y circuntancias del caso concreto, contribuir para la verdadera reconciliación" $(2009$, p. 72$)$.

No Direito Internacional, as anistias absolutas são repudiadas. Kai Ambos chega a dizer que "el derecho interncaional prohíbe de manera absolutamente inequívoca este tipo de amnistia" (2009, p. 64). Cançado Trindade (2008) afirma que uma lei de autoanistia é um grande abuso, já que é imposta pelo próprio regime agressor de direitos e garantias, destinando-se a subtrair da ação da Justiça os responsáveis por seus próprios crimes, assegurando a impunidade e encobrindo a verdade com as sombras do esquecimento. As leis de autoanistias obstruem todo esse processo 
de determinação dos fatos e de atribuição de responsabilidades aos culpados e às devidas condenações. Essa classificação se relaciona, de mais perto, com o aspecto penal da anistia. Desse modo, nada impede que haja anistia absoluta somada a meios de reparação civil e moral, pois não é por ter parte de reparação civil e moral que a anistia deixará de ser absoluta, haja vista que essa distinção se relaciona com punição ou não dos perseguidores. Nos parâmetros dessa classificação, a graça de 1979 é, sem dúvida, quanto ao modo que operou a extinção de punibilidade dos agentes do Estado da ditadura civil-militar de 1964-1985, uma anistia incondicionada, pois seu artigo primeiro buscou apagar os fatos passados sem impor nenhuma condição para tal esquecimento.

A par dessa distinção, em 2008, o STF foi provocado, pelo Conselho Federal da Ordem dos Advogados do Brasil, por meio da Ação de Descumprimento de Preceito Fundamental (ADPF), a declarar se a interpretação do parágrafo $1^{\circ}$ do artigo $1^{\circ}$ da lei $6.683 / 79$ tinha sido recepcionada pela Constituição Federal de 1988. O trecho da lei arguido foi o referente aos crimes conexos, de qualquer natureza, relacionados com crimes políticos ou praticados por motivação política e o objetivo da demanda era definir "se houve ou não anistia dos agentes públicos responsáveis pela prática de homicídio, desaparecimento forçado, abuso de autoridade, lesões corporais, estupro e atentado violento ao pudor contra opositores políticos ao regime militar" (BRASIL, 2010a, p. 04). Argumentava ainda a inicial que se o Supremo entendesse que a lei $n^{\circ} 6.683 / 79$ foi recepcionada pela nova ordem constitucional, seria imperioso interpretá-la e aplicá-la à luz da Constituição Federal de 1988, de modo que não haveria espaço para enquadrar como crime conexo os torturadores e agentes públicos que excederam os limites da própria lei do regime de exceção em razão de impedimentos de natureza processual e de preceitos e princípios fundamentais da Ordem Constitucional atual, como o preceito fundamental de não ocultar a verdade e dos princípios: republicano, isonomia e da dignidade da pessoa humana.

O plenário do STF se manifestou sobre a ADPF, em abril de 2010, ainda não tendo, portanto, conhecimento da posterior decisão da CIDH. O Supremo, por maioria, julgou improcedente a arguição, no sentido de que a Lei de Anistia foi recepcionada, devendo ser interpretada como uma anistia recíproca, sendo aplicada tanto a perseguidos quanto a perseguidores.

O ministro Eros Roberto Grau, relator da ação, entendeu que "o legislador procurou estender a conexão aos crimes praticados pelos agentes do Estado contra os que lutavam contra o Estado de exceção" (BRASIL, 2010c, p. 26), daí o caráter bilateral da anistia, assim como também não viu agressão à dignidade da pessoa humana com a extensão da conexão criminal aos agentes públicos (torturadores). Aduz que a lei decorreu de um amplo pacto/consenso social, como nos deixa perceber o parecer consultivo, ainda de 1979, da OAB. Já, no tocante à revisão da lei pelo judiciário, o STF, na ADPF $n^{\circ} 153$, manifestou-se sobre a ausência de competência do judiciário para revisar a Lei de Anistia: afirmando, por exemplo, o Ministro Eros Roberto Grau que nem mesmo o STF está autorizado a rescrever leis de anistia, haja vista que "se implicar necessária revisão da Lei de Anistia, deverá, contudo, ser feito pela lei, vale dizer, pelo Poder Legislativo. Insisto em que o Supremo Tribunal Federal não incumbe legislar sobre a matéria (BRASIL, 2010c, p. 39)". Deste modo, reforça que qualquer alteração sobre a Lei de Anistia deverá ser realizada pelo legislativo.

Esse voto foi seguido pela Ministra Carmen Lúcia, Ministra Ellen Gracie, Ministro Marco Aurélio, Ministro Celso de Mello, Ministro Cezar Peluso, Ministro Gilmar Mendes. Foram votos vencidos no sentido de julgar parcialmente procedente os Ministros Ricardo Lewandowski (entendendo que, caso a caso, deveria se analisar se o crime era ou não político) e Ayres Britto (concluindo que não deveria ser concedida anistia aos crimes constantes no artigo $5^{\circ}$, XLIII, da Constituição Federal).

Entendemos que a decisão do Supremo possui inconsistências, incoerências e erros argumentativos nos principais votos desse julgamento. Principais porque foram seguidos por 
outros ministros. Contudo, em razão do curto espaço de que dispomos, pretendemos nos deter, neste artigo, à analise de um argumento que definiu ou fortaleceu o entendimento majoritário do Tribunal, qual seja: a utilização de conceitos e jurisprudência da Corte Interamericana de Direitos Humanos para justificar a interpretação de anistia bilateral.

\section{O (DES)ACERTO NA UTILIZAÇÃO DA JURISPRUDÊNCIA DA CORTE INTERAMERICANA DE DIREITOS HUMANOS PARA JUSTIFICAR A INTERPRETAÇÃO DE ANISTIA BILATERAL PELO SUPREMO TRIBUNAL FEDERAL}

Os ministros Celso de Mello, Ayres Britto e Ricardo Lewandowski, referiram-se aos precedentes da CIDH no tocante às leis de anistia. Entendemos que Lewandowski e Britto souberam apreender o entendimento da $\mathrm{CIDH}$, estribando seu voto de modo consistente e no sentido da jurisprudência dessa corte, contudo ele não foi seguido por seus pares.

$\mathrm{O}$ voto que foi corroborado pela maioria dos ministros foi o de Celso de Mello, que afirmou que a CIDH entende como incompatível com a Convenção Americana as leis que concedem anistia unicamente para seus agentes, referendando seu entendimento sobre os casos Barrios Altos, Almonacid Arellano e Loayza Tamayo. Entendeu o Ministro, por meio de um equivocado malabarismo interpretativo, que a lei de 1979 "exatamente por seu caráter bilateral, não pode ser qualificada de autoanistia, o que torna inconsistente para os fins desse julgamento, a invocação dos mencionados precedentes da Corte Interamericana de Direitos Humanos" (BRASIL, 2010b, p. 184).

A CIDH, contudo, entende que são inadmissíveis as leis de autoanistia, de prescrição e o estabelecimento de excludentes de responsabilidade que pretendam impedir a investigação e a sanção dos responsáveis de violações contra os Direitos Humanos, tais como tortura, execução sumárias, extralegais ou arbitrárias e os desaparecimentos forçados. De modo que, como consta na sentença do caso Barrios Altos ${ }^{2}$,

las llamadas autoamnistías son, en suma, una afrenta inadmisible al derecho a la verdad y al derecho a la justicia (empezando por el propio acceso a la justicia). Son ellas manifiestamente incompatibles con las obligaciones generales indisociables - de los Estados Partes en la Convención Americana de respetar y garantizar los derechos humanos por ella protegidos, asegurando el libre y pleno ejercicio de los mismos (en los términos del artículo 1(1) de la Convención), así como de adecuar su derecho interno a la normativa internacional de protección (en los términos del artículo 2 de la Convención). Además, afectan los derechos protegidos por la Convención, en particular los derechos a las garantías judiciales (artículo 8) y a la protección judicial (artículo 25) (ORGANIZAÇÃO DOS ESTADOS AMERICANOS, 2015b).

Deste modo, a despeito do entendimento do Ministro Celso de Mello, o caráter de exclusividade não é fundamental para a definição como autoanistia, mas sim o fato de ser, como visto acima, um obstáculo para responsabilização de agentes do Estado. Para a CIDH, nem tudo que é legal do ponto de vista interno também o é sob o prisma internacional, pois sua legalidade

\footnotetext{
${ }^{2}$ Essa decisão refere-se ao caso Barrios Altos e trata da anistia de um grupo vinculado ao exército peruano, nomeado Colina, criado para realizar ações antiterroristas. Este grupo executou quinze pessoas e feriu outras quatro, todas supostamente vinculadas ao grupo Sendero Luminoso. Um ano depois, as investigações foram paralisadas, sendo retomadas em 1995, após a denúncia de participação, no grupo, de cinco oficiais do exército. Dois meses após a retomada das investigações, foi promulgada a lei 26.479 , exonerando os membros do exército que estavam sendo investigados. Em junho de 2000, entretanto, foi a julgamento, na Corte, por agressão à Convenção Americana de Direitos Humanos.
} 
en el plano del derecho interno, al conllevar a la impunidad y la injusticia, encuéntrase en flagrante incompatibilidad con la normativa de protección del Derecho Internacional de los Derechos Humanos, acarreando violaciones de jure de los derechos de la persona humana (2015b).

Ademais, afirma Cançado Trindade (2002), em seu voto, que essas anistias em nada contribuem para o bem comum, senão pelo contrário: configuram-se como meros subterfúgios para encobrir violações graves de direitos humanos; impedem o conhecimento da verdade; obstaculizam o próprio acesso à justiça por parte dos vitimados, não satisfazendo os requisitos de leis no âmbito do Direito Internacional dos Direitos Humanos. Essa decisão levou o Estado argentino a promover alterações no seu ordenamento, inclusive declarando a nulidade de suas leis de autoanistia.

$\mathrm{O}$ argumento do Ministro Celso de Mello, esbarra também no próprio precedente levantado por ele (o caso Almonacid Arellano), posto que, nesse caso, a CIDH, em verdade, despreza a discussão sobre se a lei é ou não autoanistia, firmando entendimento, hoje consolidado, que, quando as leis de graça servirem a não punição, nos casos de grave violação ao direito internacional, elas devem ser tidas como inválidas. Esse é justamente o posicionamento do Ministro Ricardo Lewandowski, haja vista afirmar que os Estados signatários do Pacto de San José da Costa Rica "têm o dever de investigar, ajuizar, punir as violações graves aos direitos humanos, obrigação que nasce a partir do momento da ratificação de seu texto" (BRASIL, 2010d, p. 129). Assim, a CIDH, ante graves violações dos Direitos Humanos, atem-se mais a impedir que fiquem impunes os agressores do que ao processo de elaboração ou à autoridade que emitiu a Lei de Anistia. Havendo, deste modo, graves violações ao direito internacional, mesmo se não fosse uma autoanistia, como no caso Almonacid Arellano contra Chile ${ }^{3}$, entende a Corte que "ao pretender anistiar aos responsáveis por crime de lesa humanidade, o decreto lei $\mathrm{n}^{\circ}$. 2.191 (Lei de Anistia chilena) é incompatível com a Convenção Americana, carecendo, portanto, de efeitos jurídicos à luz desses tratados" (ORGANIZAÇÃO DOS ESTADOS AMERICANOS, 2015a).

Ressalta-se que, à época dos crimes, o Estado chileno não havia ratificado a Convenção Americana ao decretar sua autoanistia, entretanto, como o Estado chileno manteve a referida Lei de Anistia vigente em seu ordenamento, mesmo após a posterior ratificação da Convenção, a Corte concluiu que o Estado chileno descumpriu o art. 2 da Convenção, conforme a sentença seguinte

LA CORTE, DECIDE:

Por unanimidad, que:

2. El Estado incumplió sus obligaciones derivadas de los artículos 1.1 y 2 de la Convención Americana sobre Derechos Humanos, y violó los derechos consagrados en los artículos 8.1 y 25 de dicho tratado, en perjuicio de la señora Elvira del Rosario Gómez Olivares y de los señores Alfredo, Alexis y José Luis

\footnotetext{
${ }^{3} \mathrm{O}$ caso Almonacid Arellano e outros vs. Chile, posto que a CIDH concluiu que aos crimes contra a humanidade não se pode conceder qualquer tipo de anistia. Nesse caso, ao deixar de investigar os fatos e sancionar os responsáveis, o Estado chileno descumpriu o art. 2 da Convenção Americana. O professor Almonacid era secretário provincial da Central Unitária dos Trabalhadores e candidato a alto posto do Partido Comunista. Ele foi detido em seu próprio lar e executado em frente à sua casa e aos seus familiares em 1973. Cinco anos após, foi decretada anistia para todos os delitos entre os anos de 1973 e 1978. Passados catorze anos, a viúva de Almonacid levou o caso à Corte Marcial. Nessa época, o Chile já estava em um regime democrático, no entanto, a Corte reconheceu a anistia, negando o pedido. Essa Corte sustentou que a Convenção Americana e o Pacto Internacional de Direitos Civis e Políticos eram posteriores ao crime, não lhe podendo ser aplicado. Contudo, mesmo o Estado chileno não tendo ratificado a Convenção Americana ao decretar sua autoanistia, como o Estado chileno manteve a referida Lei de Anistia vigente em seu ordenamento, mesmo após a posterior ratificação da Convenção, a Corte concluiu que o Estado chileno descumpriu a Convenção.
}

Revista de Direito Brasileira | São Paulo, SP | v. 19 | n. 8 | p. 382 - 394 |Jan./Abr. 2018 
Almonacid Gómez, en los términos de los párrafos 86 a 133 de la presente Sentencia.

3. Al pretender amnistiar a los responsables de delitos de lesa humanidad, el Decreto Ley No. 2.191 es incompatible con la Convención Americana y, por tanto, carece de efectos jurídicos, a la luz de dicho tratado.

4. Esta Sentencia constituye per se una forma de reparación (2015a).

Assim, percebemos que decisão da CIDH se direciona no sentido de afastar artifícios que os Estados de exceção criam, buscando não punir seus agentes. A CIDH não admite leis de autoanistia, pois estas estão interessadas apenas com a impunidade, sendo por completo contrárias ao Direito. Essas leis muito comuns nos Estados sul-americanos pós-ditaduras não servem como suporte para a justiça de transição, não se coadunando nem mesmo com as raízes históricas do instituto (esquecimento (amnésia) para a paz social). Desta maneira, os Estados nacionais devem se organizar internamente, de modo a efetivar os pactos internacionais de direitos humanos firmados.

É inadmissível, portanto, de acordo com a Convenção, que o Estado não revogue normas que impeçam o livre desenvolvimento dos direitos humanos, pois, conforme o art. $2^{\circ}$ da Convenção Interamericana, os Estados Partes comprometem-se a adotar, de acordo com as suas normas constitucionais e com as disposições desta Convenção, as medidas legislativas ou de outra natureza que forem necessárias para tornar efetivos os direitos e liberdades convencionados em seu artigo $1^{\circ}$.

Contudo, exercendo a soberania de suas decisões, o Estado brasileiro, por meio do STF, entendeu que a lei 6.683/79 havia sido recepcionada integralmente pela nova constituição e a interpretação dada - ainda sob a força da ditadura civil-militar, de que a anistia aos crimes políticos deveria ser estendida aos agentes do Estado que torturaram e excederam os limites do próprio estado de exceção, desprezando toda a construção internacional sobre as leis de autoanistia - deveria prevalecer.

Esse entendimento será confirmado no caso Gomes Lund contra o Brasil (ORGANIZAÇÃO DOS ESTADOS AMERICANOS, 2014c). Deste modo, em 2010, a CIDH exarou sentença punindo o Estado brasileiro em razão dos desaparecidos da guerrilha do Araguaia. A inicial da representação contra o Brasil, ante a Comissão Interamericana, foi apresentada em 07 de agosto de 1995 pelo Centro pela Justiça e o Direito Internacional (CEJIL) e por Human Rights Watch/Americas, aos quais se uniram como co-peticionários o Grupo Tortura Nunca Mais, a Comissão de Familiares de Mortos e Desaparecidos Políticos do Instituto de Estudos da Violência do Estado, e a senhora Ângela Harkavy. Em 31 de outubro de 2008, a Comissão Interamericana aprovou o Relatório de Mérito $N^{\circ}$. 91/08, concluindo que o Estado brasileiro deteve arbitrariamente, torturou ou/e desapareceu com membros do PCdoB e camponeses.

Além disso, a CIDH conclui que, em virtude da lei 6.683/79, promulgada pelo governo militar do Brasil, o Estado não levou a cabo nenhuma investigação penal para julgar e sancionar os responsáveis por esses desaparecimentos forçados; que os recursos judiciais de natureza civil com vistas a obter informação sobre os fatos não foram efetivos para garantir aos familiares dos desaparecidos o acesso à informação sobre a Guerrilha do Araguaia; que as medidas legislativas e administrativas adotadas pelo Estado restringiram indevidamente o direito ao acesso à informação desses familiares; e que o desaparecimento forçado das vítimas, a impunidade dos seus responsáveis, e a falta de acesso à justiça, à verdade e à informação afetaram negativamente a integridade pessoal dos familiares dos desaparecidos.

Mas, para nosso objeto de estudo, o mais importante foi que a CIDH declarou, por unanimidade, que por a Lei de Anistia de 1979 impedir a investigação e a sanção de graves violações de direitos humanos, o Estado brasileiro é responsável pelo desaparecimento forçado e, portanto, pela violação dos direitos ao reconhecimento da personalidade jurídica, à vida, à 
integridade e à liberdade pessoal. O Estado, portanto, descumpriu a obrigação de adequar seu direito interno à Convenção Americana sobre Direitos Humanos, como consequência da interpretação e aplicação que foi dada à Lei de Anistia a respeito de graves violações de direitos humanos.

O Brasil, assim, foi considerado responsável pela violação dos direitos às garantias judiciais e à proteção judicial, pela falta de investigação dos fatos do presente caso, bem como pela falta de julgamento e sanção dos responsáveis (militares), em prejuízo dos familiares das pessoas desaparecidas. Entendeu a CIDH que o Brasil também é responsável pela violação do direito à liberdade de pensamento e de expressão consagrado na Convenção Americana sobre Direitos Humanos, pela afetação do direito a buscar e a receber informação, bem como do direito de conhecer a verdade sobre o ocorrido; e, por fim, é responsável pela violação do direito à integridade pessoal. Essa decisão caminha ao encontro do entendimento expresso pelos ministros Ayres Britto e Ricardo Lewandowski e faz sucumbir em sua totalidade o malabarismo de Celso de Mello.

A CIDH entende que deve o Estado brasileiro conduzir eficazmente, perante a jurisdição ordinária, a investigação penal dos fatos do presente caso a fim de esclarecê-los, determinar as correspondentes responsabilidades penais e aplicar efetivamente as sanções e consequências que a lei preveja aos militares. Impõe também a Corte que seja realizado um ato público de reconhecimento de responsabilidade internacional a respeito dos fatos do presente caso, bem como que se continue com as ações desenvolvidas em matéria de capacitação para que seja implementado, em um prazo razoável, um programa ou curso permanente e obrigatório sobre direitos humanos, dirigido a todos os níveis hierárquicos das Forças Armadas. Determina também a punição, em relação aos fatos constitutivos de desaparecimento forçado, através dos mecanismos existentes no direito interno e a continuação das iniciativas de busca, sistematização e publicação de toda a informação sobre a Guerrilha do Araguaia, assim como da informação relativa a violações de direitos humanos ocorridas durante o regime militar, dentre outras. Impõe, então, a CIDH a investigação dos crimes cometidos por militares que ficaram acobertados pela Lei de Anistia.

Essa decisão vai no sentido de afastar os artifícios que os Estados de exceção criam, buscando não punir seus agentes. As disposições da Lei de Anistia brasileira, que, segundo a Corte, "impedem a investigação e sanção de graves violações de direitos humanos e carecem de efeitos jurídicos" (ORGANIZAÇÃO DOS ESTADOS AMERICANOS, 2014c), em consequência, não podem continuar a representar um obstáculo para a investigação dos fatos do presente caso, nem para a identificação e punição dos responsáveis, nem podem ter igual ou similar impacto sobre outros casos de graves violações de direitos humanos consagrados na Convenção Americana ocorridos no Brasil.

A aplicação rigorosa da lei penal nesses casos, em desfavor do esquecimento da anistia, segundo Ost (2005), é para as vítimas a primeira etapa da recuperação de sua dignidade, com a purgação coletiva de um passado traumático que deixará de assombrar seu inconsciente coletivo, sendo também a possibilidade do novo poder se impor e fazer prevalecer, para o futuro, os valores da democracia. As leis de autoanistia e as que anistiam graves violações aos Direitos Humanos, muito comuns nos Estados sul-americanos pós-ditaduras, não servem como suporte para a Justiça de Transição, não se coadunando nem mesmo com as raízes históricas do instituto (esquecimento para a paz social). Embora essas leis estejam pactuadas apenas com a impunidade, impedindo a persecução penal, trancando processos, perpetuando a injustiça, esse não foi o entendimento do Supremo Tribunal Federal. 


\section{CONCLUSÃO}

Interessante notar que o objeto deste artigo importa transconstitucionalmente tanto ao STF quanto a CIDH, pois a Lei de Anistia de 1979, como vimos, é direito que repercute tanto sobre nacionais que atravessam crises institucionais - como a transição de um regime autoritário a um democrático - quanto sobre os sistemas internacionais de proteção dos direitos humanos que julgam o Estado ante o descumprimento dos tratados por esse assinado. Assim, queda evidente que as leis de anistia nacionais dialogam abertamente com os diplomas internacionais de proteção aos direitos humanos e esse fato vincula os Estados, haja vista que, como signatários, submetem-se às cortes em caso de impedimento de investigação, processamento ou julgamento dos agentes do Estado que violaram as normas do tratado ou vilipendiaram os direitos dos presos sob sua responsabilidade.

Importante ainda considerar que, conforme elucida Doehring (2008), os direitos não se desenvolveram em instâncias apartadas. Pelo contrário, "ambas as esferas, a nacional e a internacional, se complementaram e sofreram influências mútuas, no que diz respeito ao surgimento de direitos individuais" (DOEHRING, 2008, p. 373), tanto que na Corte Permanente de Justiça Internacional e no final da $1^{\text {a }}$ Grande Guerra reconheceu-se que as normas de direitos interno deveriam também valer internacionalmente. Douzinas (2009), por outro lado, aponta que os direitos humanos são também um discurso e uma prática poderosos no Direito nacional. Por certo que essa relação entre direitos fundamentais e direitos humanos se estreitou em demasia em nosso ordenamento em virtude de a Constituição de 1988, na chamada cláusula aberta de direitos fundamentais, admitir a possibilidade de tratados internacionais de direitos humanos ratificados pelo Estado brasileiro serem incorporados ao ordenamento, a depender de seu quorum de aprovação, como norma constitucional ou infraconstitucional.

Ante tantos laços, chama atenção a falta de tom entre as duas cortes, posto que as duas decisões se contrapõem diametralmente. Entendemos que houve in casu um fechamento normativo de uma ordem perante a outra, pois o STF se negou, pelo equivocado voto de Celso de Melo, a se abrir cognitivamente à jurisprudência da $\mathrm{CIDH}$, impedindo uma possível transversalidade constitucional da matéria (NEVES, 2009). O STF, assim, ao entender que a Lei de Anistia de 1979 deve ser estendida aos militares que violaram os crimes contra a humanidade, fechou-se cognitivamente e findou confrontando a jurisprudência da $\mathrm{CIDH}$, tanto que essa corte veio posteriormente a entender que a interpretação dada à lei de 1979 fere a Convenção Americana de Direitos Humanos.

A falta de consistência no julgamento da ADPF 153 expõe a fragilidade do argumento vencedor do STF e sua total incoerência com os julgamentos da CIDH. Contudo, a solução, como estamos defendendo, não é hierarquizar uma ordem sobre a outra, mas perceber que o STF pode apreender com as escolhas feitas pela CIDH. Esse diálogo, entre ordens diferentes, conduz a uma maior consistência de suas decisões, pois, como sustenta Neves, "é fundamental a disposição de procurar as 'descobertas' normativas dos outros, para fortalecer a própria capacidade de oferecer solução para problemas comuns" (2009, p. 275). O fechamento cognitivo do STF se dá, portanto, em detrimento das construções já amadurecidas e decantadas na CIDH.

Ainda que não haja normatização internacional sobre os limites e legitimidade das leis de anistia, inúmeros julgados da Corte Interamericana de Direitos Humanos tratam do assunto, impondo critérios de legitimidade e limites formais para aceitação das leis, rechaçando as anistias que servem tão somente para proteger, sob a impunidade, agressores dos direitos humanos, como demonstram o Caso Barrios Altos e Almonacid Arellano. A jurisprudência da CIDH, em sua absoluta maioria, entende que, pela ideia de autoanistia ou pela ideia de grave violação dos direitos humanos, a lei de 1979, em seu aspecto penal, deve ser considerada sem validade, o que torna a decisão do STF - principalmente por buscar o pressuposto argumentativo da CIDH inconsistente, incoerente e desarrazoada. 
Deve, então, a corte nacional, em um esforço de abertura à decisão da CIDH, perceber que, nessa questão, é preciso levar em consideração a aplicação do direito a partir da ótica da vítima. Deste modo, como aponta Rothenburg (2013), nos casos de atos cruéis de repressão cometidos por agentes investidos do poder do Estado, como é o contexto de várias ditaduras latino-americanas, a aplicação dada a Convenção Americana de Direitos Humanos oferece, sem sombra de dúvida, um tratamento jurídico mais adequado do que o apresentado com base na relutante legislação brasileira.

\section{REFERÊNCIAS BIBLIOGRÁFICAS}

ALVES, Maria Helena Moreira. Estado e oposição no Brasil. (1964-1984). Petrópolis: Vozes, 1985.

AMBOS, Kai; MALARINO, Ezequiel, ELZNER, Gisela. Justicia de transición: informes de América Latina, Alemania, Italia y Españna. Montevideo: Konrad-Adenauer-Stiftung, 2009.

BECCARIA, Cesare. Dos delitos e das penas. Disponível em: <http://www.ebooksbrasil.org/eLibris/delitosB.html>. Acesso em: 01 jul. 2009.

BRASIL. Supremo Tribunal Federal. Ação de Descumprimento de Preceito Fundamental, no 153 6/800. Petição inicial. 2010a.

. Supremo Tribunal Federal. Ação de Descumprimento de Preceito Fundamental, $\mathrm{n}^{\mathrm{o}}$ 1536/800. Voto Ministro Celso de Mello. 2010b.

. Supremo Tribunal Federal. Arguição de descumprimento de preceito fundamental $n^{\circ}$ 153. Voto Ministro Eros Roberto Grau. 2010c.

. Supremo Tribunal Federal. Ação de Descumprimento de Preceito Fundamental, no 153 6/800. Voto Ministro Ricardo Lewandowski. 2010d.

BROWNLIE, Ian.; FARRAJOTA, Maria Manuela. Princípios de Direito Internacional Público. Lisboa: Fundação Calouste Gulbenkian, 1997.

DOEHRING, Karl. Teoria do Estado. Belo Horizonte: Del Rey, 2008.

DOUZINAS, Costas. O fim dos direitos humanos. São Leopoldo: Unisinos, 2009.

FOUCAULT, Michel. Vigiar e punir. Ed. Vozes. Petrópolis. 31 a ed. 2006.

HENFIL [Henrique de Souza Filho]. Cartas da mãe. Rio de Janeiro: Codecri, 1981.

MARTINS, Roberto Ribeiro. Liberdade para os brasileiros: anistia ontem e hoje. Rio de Janeiro: Civilização Brasileira, 1978.

MORAES, Railda Saraiva. O poder de graça. Rio de Janeiro: Forense, 1979.

NEVES, Marcelo. Transconstitucionalismo. São Paulo: Editora WMF Martins Fontes, 2009. 
O Globo. Comissão da verdade pede revogação parcial da lei da anistia responsabiliza expresidentes. Disponível em: <http://oglobo.globo.com/brasil/comissao-da-verdade-pederevogacao-parcial-da-lei-da-anistia-responsabiliza-ex-presidentes-14788798>. Acesso em: 21 abr. 2015.

ORGANIZAÇÃO DOS ESTADOS AMERICANOS. Corte Interamericana de Direitos Humanos. Caso Almonacid Arellano y otros Vs. Chile. Excepciones Preliminares, Fondo, Reparaciones y Costas. Sentencia de 26 de septiembre de 2006. Serie C No. 154. Disponível em: <http://www.corteidh.or.cr/docs/casos/articulos/seriec_154_esp.pdf>. Acesso em: 03 ago. 2015 a.

Corte Interamericana de Direitos Humanos. Caso Barrios Altos Vs. Perú. Fondo. Sentencia de 14 de marzo de 2001. Serie C No. 75. Parágrafo 2. Disponível em: <http://www.corteidh.or.cr/docs/casos/articulos/Seriec_75_esp.pdf>. Acesso em: 24 jun. 2015 b.

Corte Interamericana de Direitos Humanos. Caso Gomes Lund e outros (guerrilha do Araguaia) Vs. Brasil. Sentença de 24 de novembro de 2010. Serie C No. 219. Parágrafo 2. Disponível em: < http://www.corteidh.or.cr/docs/casos/articulos/seriec_219_por.pdf>. Acesso em: 24 jul. 2014c.

OST. François. O tempo do direito. Bauru: Edusc, 2005.

ROTHENBURG, Walter Claudius. Constitucionalidade e convencionalidade da Lei de Anistia brasileira. Rev. direito GV, São Paulo, v. 9, n. 2, p. 681-706, Dec. 2013. Disponível em: $<$ http://www.scielo.br/scielo.php?script=sci_arttext\&pid=S1808-

24322013000200013\&lng=en\&nrm=iso>. Acesso em: 22 Mai 2017.

SKIDMORE, Thomas. Brasil: de Castelo a Tancredo. 1964-1985. Tradução de Mário Salviano Silva. 4. ed. Rio de Janeiro: Paz e Terra, 1991.

TRINDADE, Vinícius Fox D. Cançado. Resenha: per non dementicare - uma análise das leis de autoanistia na evolução jurisprudencial da corte interamericana do direitos humanos. In Revista do Instituto Brasileiro de Direitos Humanos. Ano 8, Vol. 8, nº 8, 2008.

TRINDADE, Cançado A. A. Voto concordante do Juiz A. A. Cançado Trindade. In Revista do Instituto Brasileiro de Direitos Humanos, 2002. 